\title{
Isolation and identification of false positive and false negative strains on coliform dry rehydratable film
}

\author{
Seo-Hyun Lee, Kwang-Ho Mun, Na-Ye-Seul Kim, Jung-Beom Kim* \\ Department of Food science and Technology, Sunchon National University, Suncheon 57922, Korea
}

\section{대장균군 건조필름의 위양성과 위음성 균주 분리 동정}

\author{
이서현 · 문광호·김나예슬·김중범* \\ 순천대학교 식품공학과
}

\begin{abstract}
The detection efficiency on dry rehydratable films and identification of false positive and false negative colonies to improve the detection accuracy of coliform dry rehydratable films were evaluated in this study. A total of 173 commercial spices and jeotgal were used in this study. The detection accuracy for coliform on $3 \mathrm{M}$ Petrifilm coliform count film was $\mathbf{9 7 . 9 \%}$, and false negative was $\mathbf{2 . 1 \%}$ (nine strains). For Sanita-kun coliform count film, the detection accuracy was $97.3 \%$, and false positive was $2.7 \%$ (six strains). The $3 \mathrm{M}$ Petrifilm coliform count film and Sanita-kun coliform count film showed similar detection accuracies. The biochemical identification of the false negative colonies on 3M Petrifilm coliform count film revealed the presence of Escherichia hermannii and Pantoea spp., which were included in the coliform group. The false positive colonies on Sanita-kun coliform count film were identified as Bacillus licheniformis, Bacillus rhizosphaerae, Bacillus clausi, Bacillus pumilus, and Bacillus safensis, which were gram positive and oxidase positive. In order to improve the detection accuracy for coliform, it is necessary to further incubate over $48 \mathrm{~h}$ to confirm the gas generation in $3 \mathrm{M}$ Petrifilm coliform count film. In Sanita-kun coliform count film, additional biochemical tests such as the gram stain and oxidase tests are necessary.
\end{abstract}

Key words : dry rehydratable film, coliform, false positive, false negative, detection accuracy

\section{서 론}

생활수준이 향상됨에 따라 식품의 영양, 기능성과 더불 어 안전에 대한 관심이 높아지고 있으며 미생물학적 안전성 은 위생지표미생물인 대장균군의 식품 오염여부로 평가하 고 있다(1). 대장균군은 gram 음성, 호기성 또는 통성혐기성 간균으로 포자를 형성하지 않고 $35^{\circ} \mathrm{C}$ 에서 생육하며, 유당 을 분해하여 산과 가스를 생산한다. 대장균군은 장내세균 의 일종으로 식품의 불충분한 가열, 비위생적인 취급 여부

*Corresponding author. E-mail : okjbkim@sunchon.ac.kr Phone : 82-61-750-3259, Fax : 82-61-750-3208

Received 22 March 2019; Revised 08 May 2019; Accepted 03 June 2019.

Copyright (c) The Korean Society of Food Preservation. All rights reserved.
등을 판단할 수 있으며 식품 중 대장균군이 검출되면 식중 독균이 존재할 가능성이 높다. 대장균군을 검출하는 전통 적인 방법은 최확수법, 유당배지법, 데스옥시락토스배지법 등이 있으나 다수의 실험인력과 배지 준비에 장시간이 필요 한 단점이 있다. 이러한 문제점을 보완하기 위해 건조필름

이 개발되었고 식품공전(2)과 Association of Official Analytical Chemists(AOAC)(3)에 수록되어 대장균군 정성 및 정량 실험에 이용되고 있다. 건조필름은 건조된 필름위 에 미생물 생육에 필요한 영양 성분과 지시약, 억제제 등을 도포하여 시료 접종 후 24시간 배양만으로 대장균군 확인 이 가능하다. 식품공전에 수록된 건조필름에는 $3 \mathrm{M}$ 사의 Petrifilm(3M, St. Paul, MN, USA)을 이용한 건조필름 1법과 Chisso사의 Sanita-kun을 이용한 건조필름 2법이 있다. $3 \mathrm{M}$ 사의 대장균군용 Petrifilm(3M)은 두 장의 필름사이에 미생 물 생육에 필요한 yeast extract, peptic digest of animal tissue 
등의 영양성분과 lactose, 2,3,5-triphenyltetrazolium chloride (TTC) 등이 도포되어 있어 대장균군은 붉은색 집락에 기포 를 형성한다(4). Chisso사의 Sanita-kun (Chisso Corp., Tokyo, Japan)은 필름사이에 부직포가 있으며 부직포에 peptone, bonito meat extract 등 영양성분과 5-bromo4-chloro-3-indoxyl- $\beta-D$-galactopyranoside(X-gal) 등이 도포 되어 있어 대장균군은 푸른색 집락을 형성한다(5).

건조필름은 배지법에 비해 확인 동정 실험이 없고 실험 조작이 간단하여 한 번에 다량의 시료를 실험할 수 있으며, 배지 준비 과정이 생략되는 등 실험 소요시간이 짧아 식품 제조·가공업체의 자가품질검사나 식품안전관리인증기준 (HACCP) 실험에 이용되고 있다(1). 그러나 Salmonella 등 비 대장균군이 유당을 분해하여 가스를 생산할 수 있어(1), 대장균군 이외의 세균이 유당을 분해하여 붉은색 가스를 생산하는 집락을 형성할 우려가 있다. 이로 인해 확인 동정 을 실시하지 않는 건조필름법의 대장균군 실험결과는 위양 성과 위음성을 나타낼 수 있는 위험성을 내포하고 있다. 따라서 다양한 식품에 대한 대장균군 건조필름의 위양성과 위음성 미생물을 분리 동정하여 건조필름의 정확도 향상 연구가 필요하다 하겠다.

그러나 현재까지 연구결과를 살펴보면 국내의 경우 표준 균주를 이용하거나(1), 식품에 표준균주를 접종하여 실험 하는 등(1,6-8) 표준균주를 이용한 실험에 한정되어 있다. 또한 국외의 경우 대장균군에 대한 $3 \mathrm{M}$ Petrifilm(3M)의 검 출효율(9), 물중의 대장균, 대장균군에 대한 $3 \mathrm{M}$ Petrifilm(3M)의 검출효율(9), 식품 중 대장균, 대장균군에 대한 Chromocult coliform agar와 $3 \mathrm{M}$ Petrilfilm(3M)의 검출 효율(10), Sanita-kun(Chisso Corp.)을 이용한 대장균군 실험 방법 평가(11) 등 대장균군 검출효율 분석에 한정되어 있고 정확도 향상을 위해 건조필름에서 대장균군 위양성과 위음 성을 나타내는 균주에 대한 연구는 매우 미약한 실정이다. 따라서 본 연구에서는 국내 다소비 식품 중 젓갈과 향신 료(고춧가루, 후춧가루, 생강가루, 마늘가루)를 대상으로 $3 \mathrm{M}$ Petrifilm(3M)과 Sanita-kun 건조필름(Chisso Corp.)의 대장균군 검출효율을 평가하고 위양성과 위음성 균주의 생화학적 특성을 분석하여 확인시험이 없는 건조필름법의 대장균군 검출 정확도를 향상시키고자 하였다.

\section{재료 및 방법}

\section{실험재료}

본 실험에 사용된 재료는 젓갈 51 건, 고춧가루 45 건, 후춧 가루 30 건, 생강가루 30 건, 마늘가루 17 건 총 173 건을 사용 하였으며, 시중에서 유통 중인 제품을 재래시장, 대형마트 및 온라인을 통해 구입하여 사용하였다.
배지 및 시약

대장균군 검출을 위해 본 실험에 사용한 배지는 $3 \mathrm{M}$ Petrifilm coliform count(PCC; 3M, St. Paul, MN, USA), Sanita-kun coliform count(SCC; Chisso Corp., Tokyo, Japan) 를 사용하였다. 생화학적 확인 실험을 위해 nutrient agar(BD, Sparkm, MD, USA), lactose broth(BD), Gram stain kit(BioMrieux, Marcy l'Etoile, France), sporulation medium (Formedium, Norfolk, UK), carbol-fuchsin(BD), 30\% hydrogen peroxide(Daejung, Gyeonggi-do, Korea), nigrosin(SRL, Maharashtra, India), oxidase reagent(BioMerieux), O-nitrophenyl$\beta$-D-galactopyranoside(ONPG) disc(Oxoid, Hampshire, UK), motility test medium(BD), API kit(BioMerieux) 및 Vitek $\operatorname{card}(B i o M e r i e u x)$ 를 사용하였다.

\section{시료전처리}

향신료는 실온에 보관하였으며, 젓갈은 냉장고에 저장하 여 실험에 사용하였다. 검체 $25 \mathrm{~g}$ 을 정밀히 달아 멸균인산완 충액 $225 \mathrm{~mL}$ 를 가한 후 균질기(BagMixer ${ }^{\circledR} 400$, Interscience, St Nom, France)로 1분간 균질화해 시험원액으로 사용하였 으며, 멸균인산완충액을 이용하여 시험원액을 십진 희석 후 시험용액으로 하였다(2).

\section{대장균군 검출 정확도}

PCC 건조필름에서 생성된 대장균군의 전형적인 집락과 비전형적인 집락 각각 5 개씩을 선별하여 생화학적 동정을 실시하였다. SCC는 비전형적인 집락이 형성되지 않아 전형 적인 집락을 10 개씩 선별하여 실험하였다. 선별된 각각의 균주를 $35^{\circ} \mathrm{C}$ 에서 48 시간 Lactose broth에 배양해 가스 생성 유무를 확인하였다. 전형적인 집락 중 가스가 생성된 것을 대장균군 진양성으로 판정하였고, 비전형적인 집락 중 가 스가 생성되지 않은 집락을 진음성으로 판정하였다. 진양 성, 진음성, 위양성 및 위음성으로 판정된 집락수를 이용하 여 대장균군 검출 정확도를 산출하였다(12).

$$
\text { 정확도 }(\%)=\frac{\text { 대장균군 진양성 집락수+대장균군 진음성 집락수 }}{\text { 대장균군 총 검사 집락수 }}
$$

\section{위양성, 위음성 집락 생화학 동정}

전형적인 집락 중 lactose broth에서 가스가 생성되지 않 은 집락을 위양성, 비전형적인 집락 중 lactose broth에서 가스가 생성된 집락을 위음성으로 판정하여 catalase test, oxidase test, ONPG test, motility test, Gram stain, spore Stain(11,13-15)을 실시하여 판정된 생화학적 결과를 기초로 API 또는 Vitek을 이용하여 동정하였다.

위양성, 위음성 집락 분자생물학 동정

생화학동정 실험결과 정확한 동정이 이루어지지 않은 
P13-S-2, P20-S-4, G7-S-8, G30-S-7 균주는 Bionic(Seoul, Korea)에 의뢰하여 $16 \mathrm{~S}-\mathrm{rRNA}$ 유전자 염기서열을 분석하였 다. 분석된 염기서열은 Bioedit 프로그램을 이용하여 편집 한 후 National Center for Biotechnology Information의 유전 자 염기서열 정보를 이용하여 동정하였다.

\section{결과 및 고찰}

\section{대장균군 검출 정확도 비교}

건조필름에서 확인된 집락의 진양성, 위양성, 진음성, 위 음성 현황과 식품별 대장균군 검출 정확도는 Table 1 에 나타내었다. 젓갈에서 분리된 집락의 lactose broth 실험결 과 $\mathrm{PCC}$ 의 경우 전형적인 41 개 집락 모두 가스를 생산하여 진양성으로 판정되었고, 비전형적인 68개 집락 모두 가스 를 생산하지 않아 진음성으로 판정되었으며 위양성과 위음 성은 나타나지 않아 정확도는 $100 \%$ 로 산출되었다. $\mathrm{SCC}$ 의 경우 전형적인 36 개 집락 중 35 개에서 가스를 생산하여 진양성으로 판정되었고, 1 개 집락에서 가스가 생산되지 않 아 위양성으로 판정되었다. $\mathrm{SCC}$ 는 비전형적인 집락이 형성 되지 않아 진음성, 위음성은 나타나지 않았으며 정확도는 $97.2 \%$ 로 산출되었다.

고춧가루에서 분리된 집락의 lactose broth 실험결과 PCC 의 경우 전형적인 73 개 집락 모두에서 가스가 생산되어 진양성으로 판정되었고, 비전형적인 48개 집락 모두에서 가스가 생성되지 않아 진음성으로 판정되었으며 위양성과 위음성이 나타나지 않아 정확도는 $100 \%$ 로 산출되었다. $\mathrm{SCC}$ 의 경우 전형적인 36 개 집락 중 35 개에서 가스가 생성 되어 진양성으로 판정되었고, 1 개 집락에서 가스가 생성되 지 않아 위양성으로 판정되어 정확도는 $97.2 \%$ 로 산출되었다.
후춧가루에서 분리된 집락의 lactose broth 실험결과 PCC 의 전형적인 34 개 집락 모두에서 가스가 생성되어 진양성 으로 판정되었다. 비전형적인 집락 32 개 집락 중 28 개에서 가스가 생성되지 않아 진음성으로 판정되었으며, 4 개 집락 에서 가스가 생성되어 위음성으로 판정되었고 정확도는 $93.9 \%$ 로 산출되었다. SCC는 전형적인 집락 62 개 집락 중 60 개 집락에서 가스가 형성되어 진양성으로 판정되었고, 2 개 집락에서 가스가 형성되지 않아 위양성으로 판정되어 정확도는 $96.8 \%$ 로 산출되었다.

생강가루에서 분리된 집락의 lactose broth 실험결과 PCC 의 경우 전형적인 59 개 집락 모두에서 가스가 생성되었고, 비전형적인 집락 76 개 집락 중 71 개 집락에서 가스가 생성 되지 않았으며, 5 개 집락에서 가스가 생성되어 위음성으로 판정하였고 정확도는 $96.3 \%$ 로 산출되었다. $\mathrm{SCC}$ 는 전형적 인 집락 91 개 중 89 개 집락에서 가스가 형성되어 진양성으 로 판정되었고, 2 개 집락에서 가스가 형성되지 않아 위양성 으로 판정되어 정확도는 $97.8 \%$ 로 산출되었다. 마늘가루는 대장균군이 검출되지 않아 정확도를 판정하지 못하였다.

젓갈, 고춧가루, 후춧가루, 생강가루의 실험결과를 보면 $\mathrm{PCC}$ 의 경우 진양성 207 개 집락, 위양성 0개 집락, 진음성 71개 집락, 위음성 9 개 집락으로 나타나 정확도는 $97.9 \%$ 로 산출되었다. SCC는 진양성 219개 집락, 위양성 6개 집락으 로 나타나 정확도는 $97.3 \%$ 로 산출되었고, $\mathrm{PCC}$ 와 $\mathrm{SCC}$ 의 대장균군 검출 정확도는 유사하게 나타났다. 이러한 결과 는 $\mathrm{PCC}$ 의 정확도가 $98.3 \%$ 였다는 Suwansonthichai와 Rengpipat(16)의 보고와 $\mathrm{SCC}$ 의 정확도가 $96.7 \%$ 였다는 Morita 등의(17) 보고와 유사한 결과를 나타내었다. 이러한 결과를 종합하여 볼 때 $\mathrm{PCC}$ 와 $\mathrm{SCC}$ 를 사용하여 젓갈과 향신료 중 대장균군을 검출한다면 $2.1 \%$ 에서 $2.7 \%$ 의 위음 성 또는 위양성 균주가 대장균군으로 판정될 수 있었다.

Table 1. Comparison of detection accuracy in coliform dry rehydratable film

\begin{tabular}{|c|c|c|c|c|c|c|c|c|}
\hline \multirow[b]{2}{*}{ Sample } & \multirow[b]{2}{*}{ Culture medium } & \multicolumn{3}{|c|}{ Positive colonies } & \multicolumn{3}{|c|}{ Negative colonies } & \multirow{2}{*}{$\begin{array}{l}\text { Detection accuracy } \\
(\%)\end{array}$} \\
\hline & & $\begin{array}{c}\text { Number of tested } \\
\text { colonies }\end{array}$ & True positive & False positive & $\begin{array}{l}\text { Number of tested } \\
\text { colonies }\end{array}$ & True negative & False negative & \\
\hline \multirow{2}{*}{ Jeotgal } & $\mathrm{PCC}^{1)}$ & 41 & 41 & 0 & 68 & 68 & 0 & 100.0 \\
\hline & $\mathrm{SCC}^{2)}$ & 36 & 35 & 1 & - & - & - & 97.2 \\
\hline \multirow{2}{*}{ Red pepper powder } & PCC & 73 & 73 & 0 & 48 & 48 & 0 & 100.0 \\
\hline & SCC & 36 & 35 & 1 & - & - & - & 97.2 \\
\hline \multirow{2}{*}{ Pepper powder } & PCC & 34 & 34 & 0 & 32 & 28 & 4 & 93.9 \\
\hline & SCC & 62 & 60 & 2 & - & - & - & 96.8 \\
\hline \multirow{2}{*}{ Ginger powder } & PCC & 59 & 59 & 0 & 76 & 71 & 5 & 96.3 \\
\hline & SCC & 91 & 89 & 2 & - & - & - & 97.8 \\
\hline \multirow{2}{*}{ Total } & PCC & 207 & 207 & 0 & 224 & 215 & 9 & 97.9 \\
\hline & SCC & 225 & 219 & 6 & - & - & - & 97.3 \\
\hline
\end{tabular}

${ }^{1)}$ PCC: Petrifilm coliform count.

${ }^{2)}$ SCC: Sanita-kun coliform count. 
따라서 건조필름을 이용하여 대장균군을 검출할 경우 추가 적인 확인 시험이 필요한 것으로 나타났다.

\section{생화학 동정}

$\mathrm{PCC}$ 에서 확인된 9 개의 위음성 집락과 $\mathrm{SCC}$ 에서 확인된 6 개의 위양성 집락에 대한 생화학적 동정 실험 결과는 Table 2,3 에 나타내었다. $\mathrm{PCC}$ 에서 확인된 9개의 위음성 집락을 $\mathrm{SCC}$ 에 도말한 결과 푸른색의 전형적인 대장균군 성상을 나타내었고, 생화학적 동정 실험 결과 9개 집락 모두 gram 음성 단간균, catalase 양성, oxidase 음성, motility 양성, ONPG 양성 반응을 나타내었다. 이들 균주를 API 20E를
이용하여 동정한 결과 Pantoea spp.와 Escherichia hermannii 로 동정되어 위음성 집락 9균주 모두 대장균군으로 확인되 었다. Park 등(18)의 보고에 의하면 살균 온도 등 스트레스 를 받은 균주는 활성이 저하된다고 보고하였으며, 이로 인 해 생강가루, 후춧가루 제조 공정 중 가열 등 스트레스를 받은 Pantoea spp., E. hermanni와 같은 대장균군의 생육활 성이 저하되어 $3 \mathrm{M}$ Petrifilm에서 기포를 형성하지 않은 붉 은색 집락을 나타낸 것으로 판단된다. 따라서 $\mathrm{PCC}$ 를 이용 하여 대장균군을 실험할 경우 24시간 배양 후 대장균군을 판정하기 곤란하다면 48시간 이상 추가 배양하여 가스 생 성 유무를 확인하여야 할 것으로 판단된다. $\mathrm{SCC}$ 에서 확인

Table 2. Identification of false negative colony on Petrifilm coliform count

\begin{tabular}{|c|c|c|c|c|c|c|c|c|c|}
\hline \multirow{2}{*}{ Biochemical test } & \multicolumn{9}{|c|}{ Colony number } \\
\hline & P20-3M-N1 & P20-3M-N5 & P22-3M-N3 & P22-3M-N4 & G13-3M-N4 & G16-3M-N1 & G16-3M-N4 & G30-3M-N4 & G30-3M-N5 \\
\hline Lactose broth & Gas $(+)$ & Gas (+) & Gas $(+)$ & Gas (+) & Gas (+) & Gas (+) & Gas $(+)$ & Gas (+) & Gas (+) \\
\hline Gram stain & negative & negative & negative & negative & negative & negative & negative & negative & negative \\
\hline Catalase & + & + & + & + & + & + & + & + & + \\
\hline Oxidase & - & - & - & - & - & - & - & - & - \\
\hline Motility & + & + & + & + & + & + & + & + & + \\
\hline ONPG & + & + & + & + & + & + & + & + & + \\
\hline $\mathrm{PCCl})$ & $\begin{array}{l}\text { Red colony, } \\
\operatorname{gas}(-)\end{array}$ & $\begin{array}{l}\text { Red colony, } \\
\operatorname{gas}(-)\end{array}$ & $\begin{array}{l}\text { Red colony, } \\
\operatorname{gas}(-)\end{array}$ & $\begin{array}{l}\text { Red colony, } \\
\operatorname{gas}(-)\end{array}$ & $\begin{array}{l}\text { Red colony, } \\
\operatorname{gas}(-)\end{array}$ & $\begin{array}{l}\text { Red colony, } \\
\operatorname{gas}(-)\end{array}$ & $\begin{array}{l}\text { Red colony, } \\
\operatorname{gas}(-)\end{array}$ & $\begin{array}{l}\text { Red colony, } \\
\operatorname{gas}(-)\end{array}$ & $\begin{array}{l}\text { Red colony, } \\
\operatorname{gas}(-)\end{array}$ \\
\hline SCC2) & Blue colony & Blue colony & Blue colony & Blue colony & Blue colony & Blue colony & Blue colony & Blue colony & Blue colony \\
\hline API 20E & $\begin{array}{c}\text { Escherichia } \\
\text { hermannii }\end{array}$ & $\begin{array}{c}\text { Escherichia } \\
\text { hermannii }\end{array}$ & Pantoea spp. 2 & Pantoea spp. 3 & Pantoea spp. 3 & Pantoea spp. 2 & Pantoea spp. 1 & Pantoea spp. 2 & Pantoea spp. 2 \\
\hline
\end{tabular}

${ }^{1)} \mathrm{PCC}$ : Petrifilm coliform count (incubation at $35^{\circ} \mathrm{C}$ for $24 \mathrm{~h}$ )

${ }^{2}$ SCC: Sanita-kun coliform count (incubation at $35^{\circ} \mathrm{C}$ for $24 \mathrm{~h}$ )

Table 3. Identification of false positive colony on Sanita-kun coliform count

\begin{tabular}{|c|c|c|c|c|c|c|}
\hline \multirow{2}{*}{ Biochemical test } & \multicolumn{6}{|c|}{ Colony number } \\
\hline & R4-S-6 & P13-S-2 & P20-S-4 & G7-S-8 & G30-S-7 & S22-S-4 \\
\hline Lactose broth & Gas (-) & Gas (-) & Gas (-) & Gas (-) & Gas (-) & Gas (-) \\
\hline Gram stain & Positive & Positive & Positive & Positive & Positive & Positive \\
\hline Spore stain & + & + & + & + & + & + \\
\hline Catalase & + & + & + & + & + & + \\
\hline Oxidase & + & + & + & + & + & + \\
\hline Motility & + & + & + & + & + & + \\
\hline ONPG & + & + & + & + & + & + \\
\hline $\mathrm{PCC}^{1)}$ & Non-growth & Non-growth & Non-growth & Non-growth & Non-growth & Non-growth \\
\hline $\mathrm{SCC}^{2)}$ & Blue colony & Blue colony & Blue colony & Blue colony & Blue colony & Blue colony \\
\hline Vitek2 BCL & Bacillus licheniformis & - & - & - & - & Bacillus licheniformis \\
\hline 16S-rRNA sequencing & & $\begin{array}{c}\text { Bacillus rhizosphaerae } \\
\text { or } \\
\text { Bacillus clausii }\end{array}$ & $\begin{array}{c}\text { Bacillus pumilus } \\
\text { or } \\
\text { Bacillus safensis }\end{array}$ & $\begin{array}{c}\text { Bacillus pumilus } \\
\text { or } \\
\text { Bacillus safensis }\end{array}$ & $\begin{array}{c}\text { Bacillus pumilus } \\
\text { or } \\
\text { Bacillus safensis }\end{array}$ & \\
\hline
\end{tabular}

${ }^{1)} \mathrm{PCC}$ : Petrifilm coliform count (incubation at $35^{\circ} \mathrm{C}$ for $24 \mathrm{~h}$ )

${ }^{2)}$ SCC: Sanita-kun coliform count (incubation at $35^{\circ} \mathrm{C}$ for $24 \mathrm{~h}$ ) 
된 6개의 위양성 집락을 $\mathrm{PCC}$ 에 도말하여 배양한 결과 모두 생육하지 않았다. 생화학 동정 실험 결과 6개 집락 모두 gram 양성 간균, catalase 양성, oxidase 양성, ONPG 양성, motility 양성 반응을 나타내었으며 spore stain 결과 포자가 확인되었다. Vitek BCL로 실험한 결과 R4-S-6, S22-S-4는 Bacillus licheniformis로 동정되었다.

\section{분자생물학 동정}

$\mathrm{SCC}$ 에서 위양성으로 판정된 6균주 중 Vitek 실험결과 정확한 동정이 이루어지지 않은 4균주에 대하여 $16 \mathrm{~S} \mathrm{rRNA}$ 염기서열을 분석하여 동정을 실시하였다. 분자생물학적 동 정결과 P13-S-2는 Bacillus rhizosphaerae 또는 Bacillus clausii, P20-S-4는 Bacillus pumilus 또는 Bacillus safensis, G7-S-8는 Bacillus pumilus 또는 Bacillus safensis, G30-S-7는 Bacillus pumilus 또는 Bacillus safensis로 동정되어 $\mathrm{SCC}$ 에서 위양성을 나타낸 6균주 모두 그람양성의 Bacillus spp.로 동정되었다. 대장균군은 lactose가 존재할 때 $\beta$-galactosidase, lactose permease, transacetylase의 세 가지 효소를 생산하는 데, $\beta$-galactosidase는 lactose를 glucose와 galactose로 분해 하는 효소이며 lactose permease는 lactose를 세포 안으로 운반하고, transacetylase는 lactose를 아세틸화 시켜준다 (19). PCC는 lactose를 함유하고 있어 세 가지 효소가 모두 존재해야 미생물이 lactose를 분해해 산과 가스를 생성 붉은 색 집락을 나타내고 대장균군으로 판정된다. SCC는 X-gal 을 함유하고 있어 $\beta$-galactosidase, lactose permease, transacetylase의 세 가지 효소 중 $\beta$-galactosidase 한 가지 효소만 보유하고 있어도 푸른색 집락을 나타낸다. SCC는 $\beta$-galactosidase 활성 한가지로 대장균군 양성을 판단하기 에 $\beta$-galactosidase를 가지고 있으나, lactose permease, transacetylase를 가지고 있지 않은 Bacillus spp. 등 그람 양 성균이 건조필름 상에 함께 검출되는 것으로 사료된다. 따 라서 $\mathrm{SCC}$ 를 이용 대장균군을 검출할 경우 파란색 집락을 대상으로 gram stain, oxidase 생화학 실험을 통해 대장균군 을 판정하여야 할 것으로 판단된다.

\section{요 약}

본 연구에서는 $3 \mathrm{M}$ Petrifilm(3M)과 Sanita-kun 건조필름 (Chisso Corp.)의 대장균군 검출효율을 평가하고 위양성, 위음성 균주의 생화학적 특성을 분석하여 건조필름법의 대장균군 검출 정확도를 향상시키고자 하였다. 본 실험에 이용된 재료는 젓갈 51 건, 고춧가루 45 건, 후춧가루 30 건, 생강가루 30 건, 마늘가루 17 건 총 173 건을 사용하였다. $\mathrm{PCC}$ 의 대장균군 검출 정확도는 $97.9 \%$ 위음성은 $2.1 \%$ 로 나타났으며, $\mathrm{SCC}$ 의 경우 정확도 $97.3 \%$, 위양성 $2.7 \%$ 로 나 타났다. 생화학적 동정 실험 결과 $\mathrm{PCC}$ 에서 확인된 9 개의
위음성 집락은 E. hermannii와 Pantoea spp. 대장균군으로 동정되었다. 분자생물학적 동정결과 $\mathrm{SCC}$ 에서 위양성을 나 타낸 6균주 모두 그람양성의 Bacillus spp.로 동정되었다. 건조필름의 대장균군 검출 정확도를 향상시키기 위해 $\mathrm{PCC}$ 의 경우 24 시간 배양 후 대장균군을 판정하기 곤란하면 48시간 이상 추가 배양하여 가스 생성 유무를 확인하여야 할 것으로 판단된다. 또한 $\mathrm{SCC}$ 의 경우 파란색을 나타내는 집락을 대상으로 gram stain과 oxidase 생화학 실험을 통해 대장균군을 판정하여야 할 것으로 판단된다.

\section{감사의 글}

본 연구는 율촌재단의 재원을 지원 받아 수행한 연구과 제로 지원에 감사드립니다.

\section{References}

1. Park HK (2009) Evaluation of dry rehydratable film method for detection of coliform bacteria and Escherichia coli. Kor J Food \& Nutr, 22, 696-700

2. Ministry of Food and Drug Safety (2016) Korea Food Code. Ministry of Food and Drug Safety, Cheongju, Korea, p 311

3. AOAC (1990) Association of Official Method of Analysis. $15^{\text {th }}$ ed, Arlington, VA

4. Ha SD (1996) Evaluation of dryfilm method for isolation of microorganisms from foods. Kor J Appl Microbiol Biotechnol 24, 178-184

5. Ushiyama M, Iwasaki M (2010) Evaluation of Sanita-Kun E. Coli and coliform sheet medium for the enumeration of total coliforms and E. Coli. J AOAC Int, 93, 163-183

6. Cho MH, Bae EK, Ha SD, Park YS, Mok CK, Hong KP, Kim SP, Park J (2005) Evaluation of dry rehydratable film method for enumeration of microorganisms in meat, dairy and fishery products. Korean J Food Sci Technol, 37, 294-300

7. Kim KS, Bae EK, Ha SD, Park YS, Mok CK, Hong KP, Kim SP, Park JY (2004) Evaluation of dry rehydratable film method for enumeration of microorganisms in korean traditional foods. J Fd Hyg Safety, 19, 209-216

8. Park JH (2013) Comparative study on the microbial analysis using traditional medium and dry culture medium. MS Thesis, Yeungnam University, Korea, $\mathrm{p}$ 8-10 
9. Matner RR, Fox TL, Mciver DE, Curiale MS (1990) Efficacy of Petrifilm ${ }^{\mathrm{TM}}$ E. coli count plates for $E$. coli and coliform enumeration. J Food Prot, 53, 145-150

10. Schraft H, Watterworth LA (2005) Enumeration of heterotrophs, fecal coliform and Escherichia coli in water: comparison of $3 \mathrm{M}^{\mathrm{TM}}$ Petriflm ${ }^{\mathrm{TM}}$ plates with standard plating procedures. J Microbiol Methods, 60, 335-342

11. Turner KM, Restaino L, Frampton EW (2000) Efficacy of chromocult coliform agar for coliform and Escherichia coli detection in foods. J Food Prot, 63, 539-541

12. Kim JB, Kim JM, Park YB, Han JA, Lee SH, Kwak HS, Hwang IG, Yoon MH, Lee JB, Oh DH (2010) Evaluation of various PCR assays for the detection of emetic toxin producing Bacillus cereus. J Microbiol Biotechnol, 20, 1107-1113

13. Imlay JA (2008) Cellular defenses against superoxide and hydrogen peroxide. Annu Rev Biochem, 77, 755-776

14. Kim SY, Kim JD, Son JS, Lee SK, Park KJ, Park MS (2011) Biochemical and molecular identification of antibacterial lactic acid bacteria isolated from Kimchi. Korean J Food Sci. Technol, 43, 446-452
15. Park CE, Park CH (2004) Inhibition of urease activity of Helicobacter pylori by artemisia asiatica nakai. Korean J Biotechnol Bioeng, 19, 348-351

16. Suwansonthichai S, Rengpipat S (2003) Enumeration of coliforms and Escherichia coli in frozen black tiger shrimp penaeus monodon by conventional and rapid methods. Int J Food Microbiol, 81, 113-121

17. Morita H, Ushiyama M, Aoyama S, Iwasaki M, Andrews WH, Betts R, Brodsky MH (2006) Evaluation of the Sanita-Kun coliforms, a dehydrated medium sheet for coliform detection : Performance-tested method ${ }^{\mathrm{M}}$ 100402. J AOAC Int, 89, 399-416

18. Park KJ, Yoon HY, Chun SJ, Lee HS, Lee DH, Jahng DJ, Lee KH (1998) Activity and survival of the natural bacteria under the stressed conditions detected by bioluminescent phenotype. Kor J Microbiol, 34, 154-161

19. Kaback HR (2005) Structure and mechanism of the lactose permease. C R Biologies, 328, 557-567 